\title{
Colon mucosa of patients both with spondyloarthritis and Crohn's disease is enriched with macrophages expressing the scavenger receptor CD163
}

\author{
P Demetter, M De Vos, J A Van Huysse, D Baeten, L Ferdinande, H Peeters, \\ H Mielants, E M Veys, F De Keyser, C A Cuvelier
} .

Ann Rheum Dis 2005;64:321-324. doi: 10.1136/ard.2003.018382

Background: Crohn's disease is associated with an increased number of macrophages in ileal and colonic mucosa. Data on macrophages in gut mucosa of patients with spondyloarthritis (SpA) are scarce.

Objective: To investigate macrophages and other antigen presenting cells in gut mucosa from patients with $\mathrm{SpA}$ and Crohn's disease, given the relationship between both entities. Methods: Biopsy specimens from patients with SpA, Crohn's disease, ulcerative colitis, and from controls were immunohistochemically stained with different markers for macrophages and dendritic cells. Slides were scored semiquantitatively on a four point scale.

Results: SpA and Crohn's disease were associated with large numbers of $\mathrm{CD}^{+} 8^{+}$macrophages. Colon mucosa of both patients with $\mathrm{SpA}$ and Crohn's disease, but not ulcerative colitis, showed increased numbers of macrophages expressing the scavenger receptor CD163.

Conclusions: Macrophages expressing the scavenger receptor CD163 are increased in colonic mucosa in SpA and in Crohn's disease, highlighting the relationship between these entities. The increased number of $\mathrm{CDI} 63^{+}$macrophages in colon mucosa of patients with SpA suggests this is another argument for a role of macrophage scavenger receptors in this group of diseases.

$\mathrm{T}$ he Thl cytokine tumour necrosis factor $\alpha(\mathrm{TNF} \alpha)$ has a pivotal role in Crohn's disease, clearly illustrated by the effect of anti-TNF $\alpha$ drugs. ${ }^{1}$ Blocking TNF $\alpha$ also improves the articular manifestations in spondyloarthritis (SpA). ${ }^{2}$ Together with the abundant presence of TNF $\alpha$ in sacroiliac joint biopsy specimens from patients with ankylosing spondylitis, $^{3}$ this suggests a major role for TNF $\alpha$ in SpA as well.

TNF $\alpha$ is primarily produced by lymphocytes, monocytes, and macrophages. ${ }^{4}$ Besides their role in production of TNF $\alpha$, macrophages play a different part in mucosal immunity, including antigen presentation and enhancement of immunoglobulin production. An increased number of mucosal macrophages in Crohn's disease have been reported previously, ${ }^{5}$ whereas data for SpA are scarce. Studying macrophages in gut mucosa from patients with SpA, however, seems worthwhile because subclinical inflammatory gut lesions, which can evolve to clinically overt Crohn's disease, are found in $25-75 \%$ of these patients. ${ }^{6}$

This study aimed at analysing macrophages and other antigen presenting cells in gut mucosa from patients with SpA and Crohn's disease. The results were compared with those obtained in ulcerative colitis and controls. Special attention was paid to the macrophage scavenger receptor CD163, because $\mathrm{CDI}^{+} 3^{+}$macrophages are increased in synovium from patients with SpA compared with patients with rheumatoid arthritis. ${ }^{7}$

\section{METHODS}

\section{Patients with SpA}

Ileal and colonic biopsy specimens were obtained from 21 patients with SpA fulfilling the European Spondylarthropathy Study Group criteria. ${ }^{8}$ This group included patients with ankylosing spondylitis $(n=16)$, psoriatic arthritis $(n=2)$, reactive arthritis $(n=1)$, juvenile $\operatorname{SpA}(n=1)$, and undifferentiated SpA $(\mathrm{n}=1)$. Their median age was 36.5 years (range 26-74). Six patients were taking sulfasalazine and 11 were receiving non-steroidal anti-inflammatory drugs. One of the patients was treated with corticosteroids. The remaining patients had no drug treatment.

As all tissue from these patients was collected during the past 4 years, there was no longer follow up period. Over that time, one of them developed a clinical Crohn's-like colitis, confirmed histopathologically.

\section{Patients with inflammatory bowel disease}

Mucosal biopsy samples from resection specimens were obtained from patients with Crohn's ileitis $(n=10)$, Crohn's ileocolitis $(n=4)$, Crohn's colitis $(n=6)$, and ulcerative colitis $(n=11)$. The diagnosis was independently established by endoscopic, radiological, and histological criteria. Samples were taken from areas with endoscopic or macroscopic involvement. The median age of the patients with Crohn's disease was 31 years (range 13-67), and of those with ulcerative colitis 37 years (range 29-61). Twenty five patients with inflammatory bowel disease (IBD) were treated with corticosteroids or other immunosuppressive drugs; four patients were taking only sulfasalazine. The remaining two patients had no drug treatment.

\section{Controls}

Control ileal and colonic tissue was obtained from 13 patients who underwent a segmental colectomy for colorectal carcinoma, or a colonoscopy for irritable bowel syndrome or follow up of polyps. In cases of carcinoma, samples were taken at least $10 \mathrm{~cm}$ away from the tumour. The median age of these patients was 56 years (range 27-72).

This study was approved by the local ethical committee.

Abbreviations: IBD, inflammatory bowel disease; SRCR, scavenger receptor cysteine-rich; SpA, spondyloarthritis; TNF $\alpha$, tumour necrosis factor $\alpha$ 


\begin{tabular}{|llll|}
\hline \multicolumn{2}{l}{ Table 1 Antibodies used in this study } \\
\hline Antibody & CD group & Major specificity in normal lymphoid tissues & Source \\
\hline TÜK4 (lgG2a) & CD14 & Monocytes & DAKO \\
EBM11 (lgG1) & CD68 & Monocytes and macrophages & DAKO \\
N-20 (polyclonal lgG) & CD80 & B7-1 (antigen presenting cells) & Santa Cruz \\
& & Biotechnology \\
HB15A (lgG2b) & CD83 & Dendritic cells & Immunotech \\
BU63 (lgG1) & CD86 & B7-2 (resting monocytes and dendritic cells) & DAKO \\
Ber-MAC3(lgG1) & CD163 & Activated monocytes, macrophages & DAKO \\
TAL.1B5 (lgG1) & - & HLA-DR, $\alpha$ chain (monocytes, macrophages, & DAKO \\
& & dendritic cells, B cells) & \\
& & & \\
\end{tabular}

\section{Immunohistochemistry}

Frozen sections of ileal and colonic mucosa from all patients and controls were fixed in acetone and incubated with antibodies against CD68 and CD163. Moreover, we performed stainings for CD14, CD80, CD83, CD86, and HLA-DR on ileal and colonic mucosa from all controls and all patients with ulcerative colitis, Crohn's ileitis, and Crohn's ileocolitis, and from 10 patients with SpA and five with Crohn's colitis. Table 1 lists the antibodies used.

Immunostaining was visualised using new fuchsin (for CD68) or 3-amino-9-ethylcarbazole (for the other markers), both obtained from DAKO Corporation (Carpintera, USA).
Parallel sections were incubated with irrelevant isotype and concentration matched antibodies as negative control.

\section{Evaluation of immunohistochemical staining}

The number of positive cells in the lamina propria was analysed using magnification $\times 100$ and coded by two independent observers who did not know the diagnosis and clinical data. A grading scale from 0 to 3 was applied, ranging from absent to numerous stained cells. As some histological markers are more abundant than others in gut tissue, the scoring system was calibrated for each marker separately by examining a representative number of samples. Thus, the
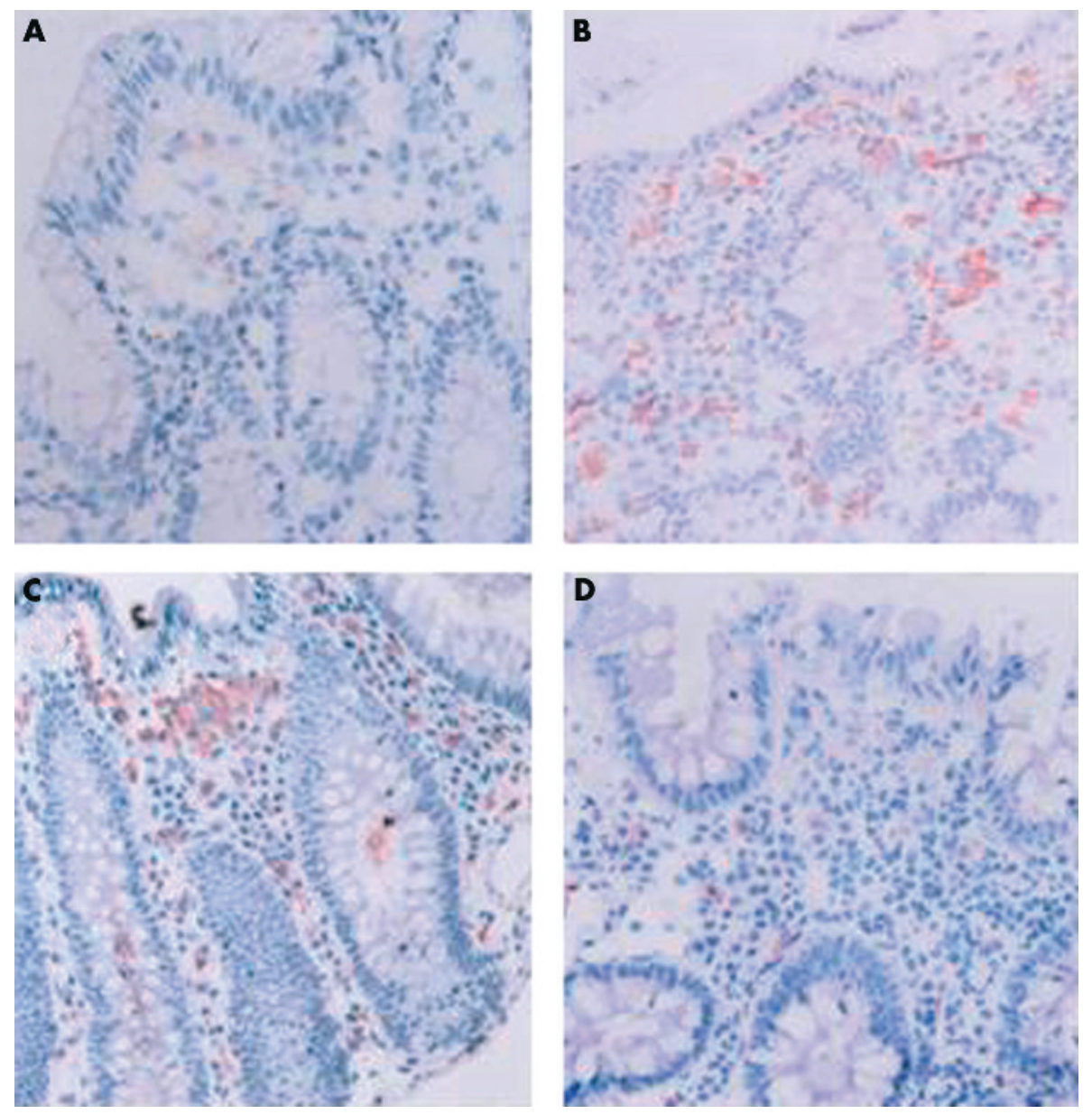

Figure 1 Immunohistochemical staining for CD163 (peroxidase method). (A) Macrophages weakly positive for CD163 in the superficial lamina propria of control colon. (B) Increase in the number of CD163 cells in Crohn's colitis. (C) Non-inflamed colonic mucosa from a patient with SpA showing a similar increase in the number of activated macrophages. (D) No increase in the number of CD163+ cells in ulcerative colitis. 

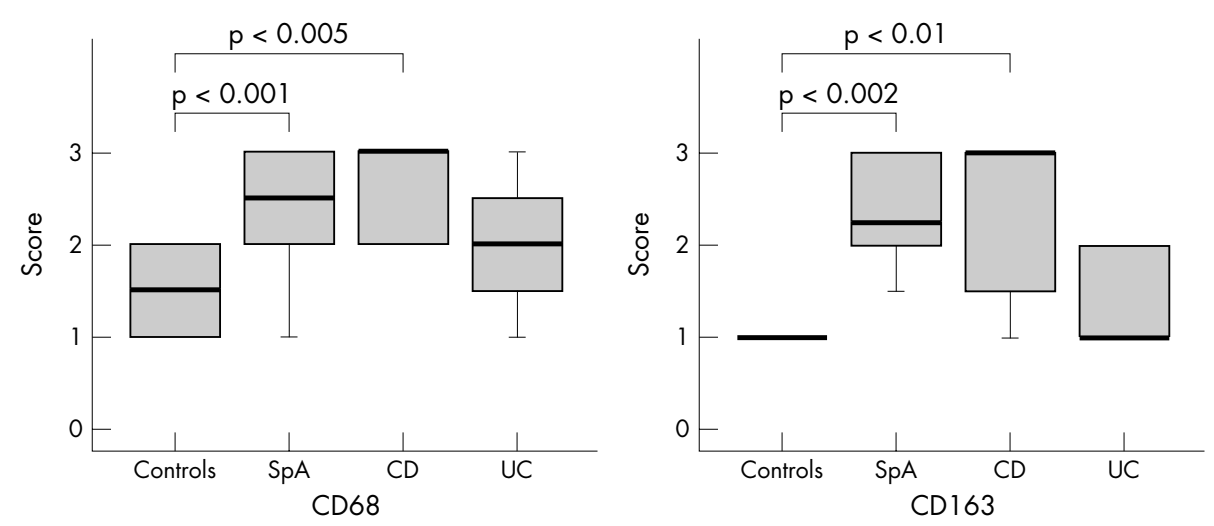

Figure 2 Box and whisker plots representing the semiquantitative scores for CD68 and CD163 in the colonic lamina propria of patients with spondyloarthritis (SpA), Crohn's disease (CD), and ulcerative colitis (UC) compared with controls. $p$ Values were calculated with the Mann-Whitney U test.

sensitivity of the scoring system was different for each marker, allowing comparison of a specific marker between the different patient groups, but not comparison of different markers in one group. The analysis included all areas of the biopsy specimens, and a global score was given for each measure.

The scores obtained by both observers were concordant in more than $90 \%$ of cases. When the scores were discordant, differing by a maximum of one point, the mean of the two scores was used.

\section{Statistical analysis}

Patient groups were compared with controls; $p$ values were calculated with the Mann-Whitney U test. A value of $\mathrm{p}<0.05$ was considered significant.

Because the data were not compared between multiple groups and because the analysis of each marker was considered as an individual comparison between two groups, Bonferroni corrections for multiple comparisons were not applied in this exploratory study.

\section{RESULTS}

\section{Increased number of CD $163^{+}$macrophages in both} Crohn's colitis and colon mucosa from patients with SpA

Control ileum and colon showed a subepithelial band of $\mathrm{CD}^{+} 8^{+}$macrophages. In patients with inflammatory disease multitudinous $\mathrm{CD} 68^{+}$cells were found in the ulcer bases; they were especially numerous in transmural inflammation in Crohn's disease. $\mathrm{CD}^{+} 8^{+}$cells were increased in ileal $(\mathrm{p}<0.02)$ and colonic $(\mathrm{p}<0.01)$ Crohn's disease and also in colon from patients with SpA $(\mathrm{p}<0.005)$.

In controls, $\mathrm{CDI} 63^{+}$macrophages were also localised in the superficial lamina propria of the colon (fig lA) and in ileal villous tips, but they were less numerous than $\mathrm{CD}^{+} 8^{+}$cells. Scarce $\mathrm{CDI} 63^{+}$cells were found in the deeper layers of the lamina propria. Crohn's colitis showed increased numbers of $\mathrm{CDI}^{+} 3^{+}$cells throughout the mucosa $(\mathrm{p}<0.01)$ (fig $\left.1 \mathrm{~B}\right)$. In colon from patients with SpA, increased numbers of $\mathrm{CD} 63^{+}$ cells were also detected $(\mathrm{p}<0.002)$ (fig $\mathrm{lC}$ ). This contrasts with the normal findings in ulcerative colitis (fig lD). Figure 2 presents the results for the scores for CD68 and CD163 in colon.

\section{The number of dendritic cells and HLA-DR positive inflammatory cells is unaltered in the mucosa of patients with IBD or SpA}

$\mathrm{CD} 3^{+}$cells were present in $\mathrm{T}$ cell zones of lymphoid follicles in both normal and inflamed bowel mucosa. Although outside the follicles fewer $\mathrm{CD}^{+} 3^{+}$cells were found, clusters of positive cells were present in IBD but not in controls and patients with SpA.

$\mathrm{CD}^{+} 0^{+}$cells were scarce. $\mathrm{CD} 86^{+}$cells occurred scattered throughout the lamina propria and could be found in the dome area overlying lymphoid follicles; in follicles, however, they were scarce or absent. There was no increase in patient groups.

In all cases, HLA-DR ${ }^{+}$inflammatory cells were found in the lamina propria. No significant differences between patients and controls were found.

\section{DISCUSSION}

We demonstrated an increased number of $\mathrm{CD} 63^{+}$macrophages in colon from patients with SpA and from those with Crohn's disease, but not ulcerative colitis. The number of $\mathrm{CDI} 63^{+}$cells was not related to the patient's age or drug treatment (data not shown).

The transmembrane protein $\mathrm{CDl} 63$ is a member of the scavenger receptor cysteine-rich (SRCR) superfamily. The SRCR proteins play a part in the development of the immune system and in the regulation of the immune response. Although the precise function of CD163 is unknown, a role in the regulation of the immune response of macrophages is supposed. Comparison of $\mathrm{CDI}_{63}^{-}$and $\mathrm{CD} 163^{+}$swine monocytes/macrophages showed that the latter are more mature.' $\mathrm{CDI} 63^{+}$cells induce a greater allogeneic response on $\mathrm{T}$ lymphocytes. Lipopolysaccharide stimulated $\mathrm{CDI}^{-}$and $\mathrm{CD} 63^{+}$macrophages both produce the proinflammatory cytokines interleukin $\mathrm{l}$ and $\mathrm{TNF} \alpha$, but anti-inflammatory interleukin 10 is only detected on the former population. ${ }^{9}$

An increase of $\mathrm{CDI} 3^{+}$macrophages in colon mucosa in SpA as well as Crohn's disease raises the possibility that these cells may induce a similar dysregulation of the cytokine balance in the colon in both disorders. Previously, we described also for $\mathrm{T}$ cells common characteristics in the cytokine profile. ${ }^{10}{ }^{11}$ These observations, together with similar alterations in adhesion molecule expression, ${ }^{12}{ }^{13}$ are in line with the concept that some patients with SpA have subclinical Crohn's disease.

The CD163 protein scavenges haemoglobin by mediating endocytosis of haptoglobin-haemoglobin complexes. ${ }^{14}$ Compounds containing haem are potentially a valuable source of iron for invading micro-organisms; although bacteria have evolved several strategies to overcome iron shortage, increased scavenging of haptoglobin-haemoglobin complexes might alter the composition of the bacterial gut flora. 
In conclusion, this study indicates that $\mathrm{CD} 63^{+}$macrophages are increased in colonic mucosa in SpA as well as in Crohn's disease, highlighting the relationship between these entities. Because the macrophage receptor with collagenous structure is also susceptible to modulation in $\mathrm{SpA},{ }^{15}$ we suggest this is another argument for a role of macrophage scavenger receptors in this group of diseases. However, CDl63 is the first scavenger receptor shown to be altered in colon mucosa from patients with SpA.

\section{ACKNOWLEDGEMENTS}

This work was supported by concerted action grant GOA96001 of Ghent University, FWO-Vlaanderen grant 3.0028.95, and Ghent University Research Foundation grant 00/DOC/017.

\section{Authors' affiliations \\ P Demetter, J A Van Huysse, L Ferdinande, C A Cuvelier, Department of Pathology, Ghent University Hospital, Ghent University, Belgium \\ M De Vos, H Peeters, Department of Gastroenterology, Ghent University Hospital, Ghent University, Belgium \\ D Baeten, H Mielants, E M Veys, F De Keyser, Department of Rheumatology, Ghent University Hospital, Ghent University, Belgium}

Correspondence to: Dr P Demetter, Department of Pathology, Ghent University Hospital, 5 Blok A, De Pintelaan 185, B-9000 Gent, Belgium; pieter.demetter@ugent.be

Accepted 6 May 2004

Published Online First 28 May 2004

\section{REFERENCES}

1 Bell S, Kamm MA. Antibodies to tumour necrosis factor alpha as treatment for Crohn's disease. Lancet 2000;355:858-60.

2 Van den Bosch F, Kruithof E, Baeten D, Herssens A, De Keyser F, Mielants H, et al. Randomized double-blind comparison of chimeric monoclonal antibody to tumor necrosis factor alpha (infliximab) versus placebo in active spondylarthropathy. Arthritis Rheum 2002;46:755-65.
3 Braun J, Bollow M, Neure L, Seipelt E, Seyrekbasan F, Herbst H, et al. Use of immunohistologic and in situ hybridization techniques in the examination of sacroiliac joint biopsy specimens from patients with ankylosing spondylitis. Arthritis Rheum 1995;38:499-505.

4 Pennica D, Nedwin GE, Hayflick JS, Seeburg PH, Derynck R, Palladino MA, et al. Human tumour necrosis factor: precursor structure, expression and homology to lymphotoxin. Nature 1984;312:724-9.

5 Thyberg T, Graf W, Klingenstrom P. Intestinal fine structure in Crohn's disease. Lysosomal inclusions in epithelial cells and macrophages. Virchows Archiv[A] 1981;391:141-52.

6 De Vos M, Mielants H, Cuvelier C, Elewaut A, Veys E. Long-term evolution of gut inflammation in patients with spondyloarthropathy. Gastroenterology 1996;110:1696-703.

7 Baeten D, Demetter P, Cuvelier C, Kruithof E, Van Damme N, De Vos M, et al. Macrophages expressing the scavenger receptor CD163: a link between immune alterations of the gut and synovial inflammation in spondyloarthropathy. J Pathol 2002;196:343-50.

8 Dougados M, van der Linden S, Juhlin R, Huiffeldt B, Amor B, Calin A, et al. European Spondylarthropathy Study Group preliminary criteria for the classification of spondylarthropathy. Arthritis Rheum 1991;34:1218-27.

9 Sanchez C, Domenech N, Vazquez J, Alonso F, Ezquerra A, Dominguez J. The porcine $2 A 10$ antigen is homologous to human $C D 163$ and related to macrophage differentiation. J Immunol 1999;162:5230-7.

10 Van Damme N, De Vos M, Baeten D, Demetter P, Mielants H, Verbruggen G, et al. Flow cytometric analysis of gut mucosal lymphocytes supports an impaired Th1 cytokine profile in spondyloarthropathy. Ann Rheum Dis $2001 ; 60: 495-9$

11 Van Damme N, De Keyser F, Demetter P, Baeten D, Mielants H, Verbruggen $G$, et al. The proportion of Thl cells, which prevail in gut mucosa, is decreased in inflammatory bowel syndrome. Clin Exp Immunol $2001 ; 125: 383-90$.

12 Demetter P, Baeten D, De Keyser F, De Vos M, Van Damme N, Verbruggen G, et al. Subclinical gut inflammation in spondyloarthropathy patients is associated with upregulation of the E-cadherin/catenin complex. Ann Rheum Dis 2000:59:211-16.

13 Demetter P, De Vos M, Van Damme N, Baeten D, Elewaut D, Vermeulen S, et al. Focal upregulation of E-cadherin/catenin complex in inflamed bowel mucosa, but reduced expression in ulcer-associated cell lineage. Am J Clin Pathol 2000; 114:364-70.

14 Kristiansen M, Graversen JH, Jacobsen C, Sonne O, Hoffman HJ, Law SK, et al. Identification of the haemoglobin scavenger receptor. Nature 2001:409:198-201.

15 Seta N, Granfors K, Sahly H, Kuipers JG, Song YW, Baeten D, et al. Expression of host defense scavenger receptors in spondylarthropathy. Arthritis Rheum 2001;44:931-9. 